\title{
Customers' perception of information security in internet banking
}

\author{
Nikola Milosavljević \\ Quality Management and Standardization \\ Student of Faculty of Organisational Sciences \\ Belgrade, Serbia \\ nikola97ks@gmail.com
}

\begin{abstract}
Information Security is one of the key segments for every organization that gathers customers' information. This paper reviews customers' perception of information security in internet banking, their needs regarding security of information and their familiarity with some of the concepts related to Information Security. Online questionnaire was used in this paper as method for collecting data that will be used in this research. After conducted questionnaire, statistical analysis was performed using SPSS 23 , and various tests (T-test, ANOVA) were used in order to get most precise data.
\end{abstract}

Keywords-Information Security, Internet banking, Customers' perception

\section{INTRODUCTION}

As technology has developed and evolved, the reliance by every organization upon Information and Communication Technology (ICT) has increased dramatically [1], and ICT have affected all the industries such as insurance, health, banking, transportation, private organization, military and government [2].

One of the most important resource that company can possesses is information [3,4], and because of that modern world, society, institutions and organizations are becoming dependent on information technology [3]. With the advent of globalization and ever changing technologies the need for information security is becoming more and0 more vital [3]. Information security and security in general is an issue of increasing importance [2,5]. Areas such as physical, platform, communication, network and application all have impact on security and they all have their own specific threats, risks and solutions [2]. Maintaining the security of information requires serious effort and approach involving managers, employees, and support personnel, no matter in which sector of organization they work. [6].

Secure and safe information environment is crucial to most of the organizations. Information that information system provides must be with the highest feasible level of:

- Confidentiality by making sure only people who have legitimate right can have an access

- Integrity for securing the information from being malevolently or purposely changed

\author{
Sara Njagojević \\ Quality Management and Standardization \\ Student of Faculty of Organisational Sciences \\ Belgrade, Serbia \\ sara.njagojevic@gmail.com
}

- Availability by making information accessible to authorized staff when and where it is needed $[7,8]$.

Security incidents are happening almost every day, and they are caused by hackers, spam, viruses, spyware, zombie networks and many other threats. These incidents can have significant impact on the economy and society by violating human rights and a lot of organizations have suffered failures, serious losses and extinction due to lack of security, privacy and governance of this asset $[9,10]$.

Many people hesitate or reject to accept new technologies such as internet banking systems or new IT appliances because of security and privacy issues and whether that will happen depends not only on its actual security level, but it also depends on perceived security [11]. Despite that, not a lot of research has been done to study people's perception of information security [10]. Perceived information security is defined as the consumer's opinion about likelihood with which their personal information will not be manipulated, viewed or stored during transmission or storage by improper participants [12]. Once customers expose personal information and lose control over it, they naturally feel worried about what will happen with their information [13].

In the field of services, in order to increase customer repurchase intention, it is important to improve service quality. Improving service quality requires boosting customer satisfaction which can be achieved through awareness of real customer perception of service experience. In order to understand customer perception, the key determinants of customer expectations must be identified [14]

There have been many research studies regarding customer expectations in a various context, but it have been usually analyzed from the aspect of customer satisfaction and dissatisfaction, and service quality [15].

The gaps between customer expectations and their perceptions of the service they get which are established depending on service provider's services and behavior is recognized as service quality [9]. The roots of information security can be found in total quality management. In Total Quality Management (TQM) customers requirements and expectations and the objectives of the organizations are achieved in an competent and cost-effective way. According to some 
research studies, service quality is a essential determinant of customers' satisfaction, positive wordof-mouth, buying decisions and long-term loyalty [15].

The banking sector, as one of the fastest growing industries, has embraced internet banking as a delivery channel for their services. The point of e-banking is to provide the banking services electronically instead of the traditional banks' branches. Online banking is delivering all the services offered by the banks at the customers' home computer, tablet or mobile phone. Customer can use most of the banking services online, like balance reporting and transactions of funds without going to the bank at all [16].

Online banking has many benefits over traditional banking because the service is available $24 \mathrm{~h}$ per day, branch operating hours is reduced and queues are being eliminated, etc. It helps banks to keep existing customers, increase customer's satisfaction and banks' market share, while decreasing administrative and operational cost and improve banks' competitiveness [17].

Internet banking is now widespread around the world due to its convenience and low cost. As reported by American Bankers' Association (ABA) survey done in August 2014, internet banking is America's most popular banking method with $31 \%$ of customer prefering it.

In the context of Internet banking, security and privacy are specified as "a potential loss due to fraud or a hacker compromising the security of an online bank user". Security and privacy and confidentiality of personal information are among the biggest concerns for banks and internet banking customers [11].

Financial Fraud Action UK (FFA) stated that losses related to internet banking frauds in the UK reached $£ 40.9 \mathrm{~m}$ in 2014 .

Many studies have been conducted regarding this problem, but at the same time, most of these researches consider employee security awareness in organizations, while only few of them have been analyzing customer awareness of internet banking security [18].

\section{LITERATURE REVIEW}

Information security has become a major problem and concern for both organizations and customers, so it is very important to learn more about people's perception of information security [10]. Some authors suggested that further research should be concentrating on the connection between people's perception of information security and their viewpoint toward information technology, and the factors that contribute to the perceived information security [10].

Reference [9] showed that information security governance as one of the parts of corporate governance urges information security service. This can help organizations to deal with information security risks through providing stable service quality meeting the expectations of their customers, learning about customer expectations and reducing the gap between customer perception and expectations.

Reference [5] is focusing on consumers' problems related to online privacy in Germany. According to their results consumers' views about internet privacy and online behaviors are mostly influenced by their views related to privacy generally and their opinion about the role of the government and companies in protecting consumer privacy.

Reference [4] conducted a research where customers were exposed to three security related scenarios (negative, neutral and positive) in the hotel industry and then measured different effects on customers' perception of service quality, customers satisfaction, referral likelihood, and revisit intentions. In the first two scenarios where breach happened, no matter if the customers' credit card data were stolen, the results of the research showed negative outcomes. Third scenario, where customers were told that hotel had just passed a comprehensive information system security check, resulted in increased satisfaction and revisit intentions.

Reference [19] researched how confidentiality, integrity, availability, privacy and verification effect perceived information security in internet banking systems. Confidentiality and privacy have substantial positive effect on perceived information security, while availability, integrity and verification are not viewed as important factors by the customers.

Reference [12] proposed a set of antecedents (encryption, protection, verification and authentication) to perceived security from visible technology mechanisms and for this reason perceptible to the consumers. Protection, which insinuates consumers' perceptions of how secure their stored information are, and encryption, which shows how their information was handled during transmission were proved to be influential factors of perceived security.

Reference [20] indicated that privacy and security are main issues of dissatisfaction with the use of mobile and internet banking while possibility of losing money to fraud is what consumers are mostly concerned about. It is also stated that the lower the perception of risk associated with using mobile banking, the more likely it will be accepted. Reference [21] concluded that security and standardization of services are the crucial issues and challenges in mobile banking today which need to be dealt with, according to consumers.

Reference [18] conducted a research study about customer awareness of internet banking security in which are presented his illuminating findings:

- Customers are not very familiar with internet banking security

- Customers are not familiar with basic technologies and main threats of internet banking 
- Customers are concerned about internet banking security

- Customers don't actively care about internet banking security

- The existing security information is not very useful

- Every channel has its own benefits for customers

- The utilization of advanced devices may backfire.

While over $60 \%$ of customers either agree/strongly agree that internet banking is secure, over $50 \%$ of nonusers disagree/strongly disagree [18].

\section{RESEARCH METHODOLOGY}

\section{A. Aim of this research}

The aim of this research is to examine the needs of internet banking customers regarding security of information. As well the aim of this study is to examine how familiar they are with information security, how much security of their information is important to them and how different kinds of security would breaches affect their attitude towards internet banking.

\section{B. Research questions and hypothesis}

Research Question 1: How familiar are customers with basic technologies and the main threats of internet banking

Research question 2: Customers are concerned about internet banking security

Research question 3: Customers consider internet banking is secure

Hypothesis 1: There is a difference in familiarity with basic technologies and the main threats of internet banking between sexes.

Hypothesis 2: Internet banking customers know the correct web address of their banks

\section{Population and sample charateristics}

The population of this research are people from Serbia, both users and non users of internet banking. Online questionnaire was used in this paper as method for collecting data that will be used in this research. The sample size is 118 respondents. We can see more about respondents from the graphs below.

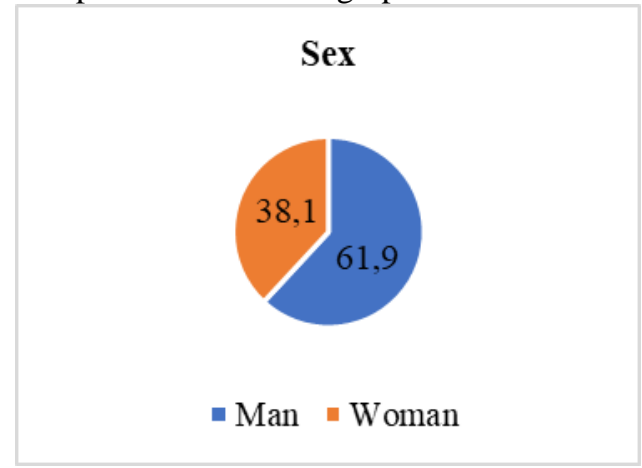

Fig. 1. Sex of respondents

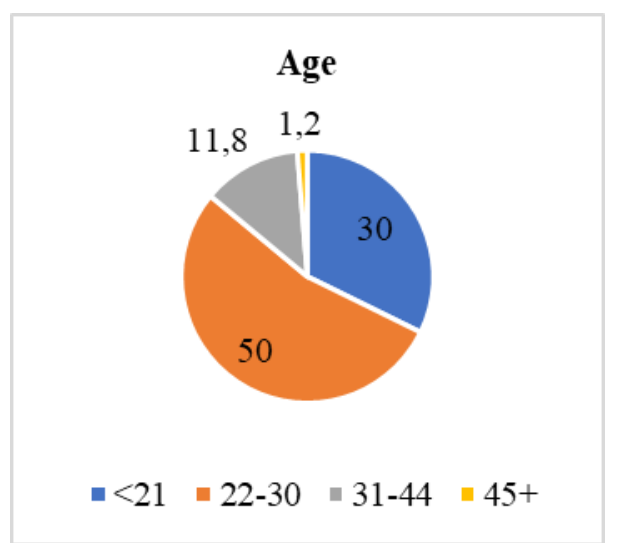

Fig. 2. Age of respondents

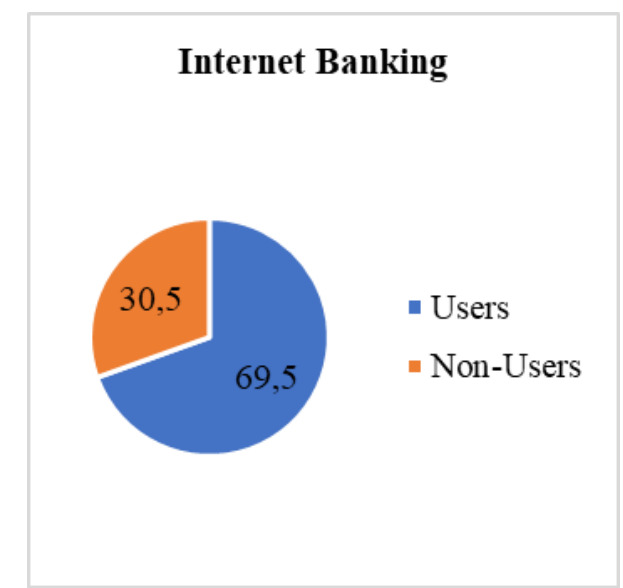

Fig. 3. Internet banking customers

\section{Research instruement}

Questionnaire was created and distributed online. It was consisted of five parts. First one was related to basic demographic questions including sex, age, the purchasing power and level of education. Second part included questions about their usage of internet banking, while third one contained the questions about importance of information security to the respondents, and how familiar they are with some technical aspects of IS. Questions in the fourth part examined the needs of the internet banking customers. Last part was consisted of questions sorted in different scenarios regarding security breaches.

\section{E. Data Analysis Methodes}

After conducted questionnaire, statistical analysis was performed using SPSS 23, and various tests ( $\mathrm{T}$ test, ANOVA) were used in order to get most precise data.

\section{RESULTS}

A. Research Question 1: How familiar are customers with basic technologies and the main threats of internet banking

There were four questions regarding how much are customers familiar with some of the basic technologies and the main threats of internet banking (SSL, phishing, digital certificates and dynamic 
passwords). As it can be seen from the tables below, most of the respondents never heard of these technologies or they only heard about them, but they don't know what these are.

TABLE I. FAMILIARITY WITH IS DYNAMIC PASSWORDS

\begin{tabular}{|c|r|r|}
\hline Familiar with dynamic passwords & Frequency & Percent \\
\hline Never heard of it & 59 & 50,0 \\
Just heard of it & 27 & 22,9 \\
Know what it is & 25 & 21,2 \\
Totally familiar & 7 & 5,9 \\
Total & 118 & 100,0 \\
\hline
\end{tabular}

TABLE II. FAMILIARITY WITH IS PHISHING

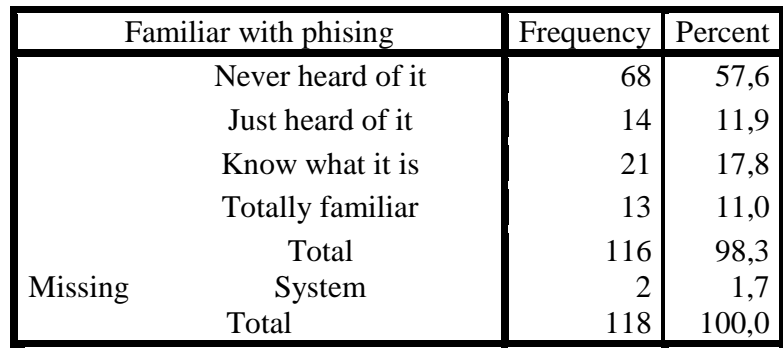

TABLE III. FAMILIARITY WITH IS SSL

\begin{tabular}{|c|c|c|c|}
\hline \multicolumn{2}{|c|}{ Familiar with SSL } & Frequency & Percent \\
\hline & Never heard of it & 71 & 60,2 \\
\hline & Just heard of it & 15 & 12,7 \\
\hline & Know what it is & 17 & 14,4 \\
\hline & Totally familiar & 13 & 11,0 \\
\hline & Total & 116 & 98,3 \\
\hline Missing & System & 2 & 1,7 \\
\hline & Total & 118 & 100,0 \\
\hline
\end{tabular}

TABLE IV. FAMILIARITY WITH IS DIGITAL CERTIFICATES

\begin{tabular}{|c|r|r|}
\hline Familiar with digital certificates & Frequency & Percent \\
\hline Never heard of it & 51 & 43,2 \\
Just heard of it & 28 & 23,7 \\
Know what it is & 32 & 27,1 \\
Totally familiar & 7 & 5,9 \\
Total & 118 & 100,0 \\
\hline
\end{tabular}

B. Research question 2: Customers are concerned about internet banking security

This is proven not to be true. It seems like customers are not really concerned about their internet banking security because most of the respondents said that they strongly disagree/disagree.

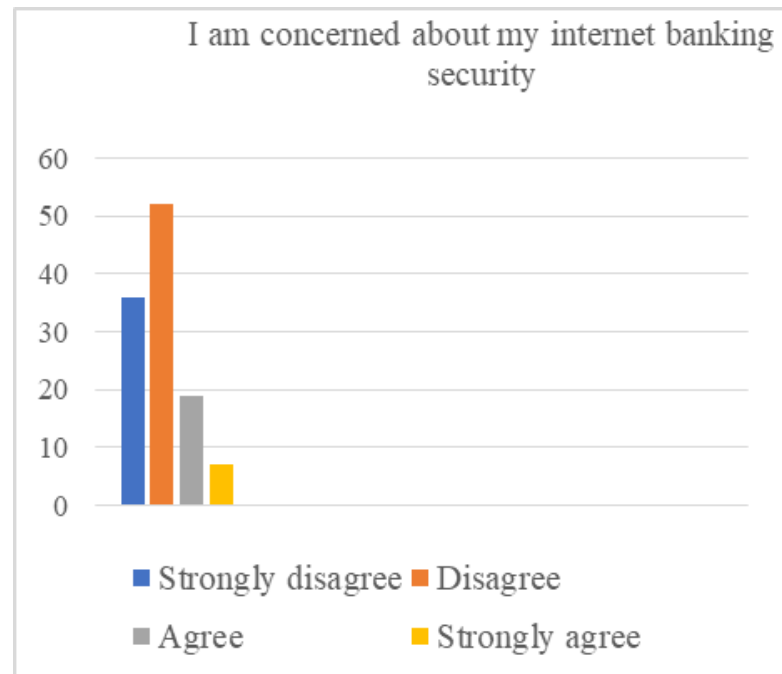

Fig. 4. Concerned about internet banking security

\section{Research question 3: Customers consider internet} banking is secure

Results have shown that this is mostly true. $93 \%$ of the answers were that they agree/strongly agree.

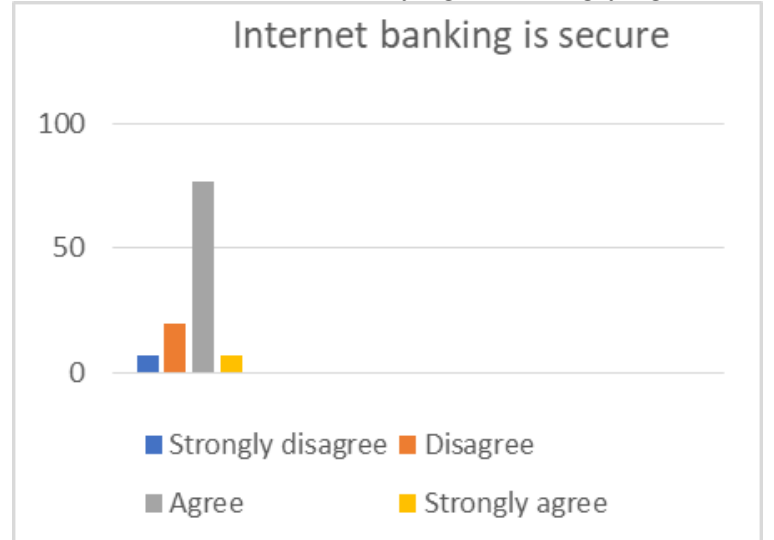

Fig. 5. Internet banking is secure

\section{Hypothesis 1: There is a difference in familiarity} with basic technologies and the main threats of internet banking between sexes

Using t-test it can be proven that this is right for every of the four questions that was asked regarding this issue. Significant influence does exist and it is less than 0.05 . The results of this research are given in the table. 
TABLE V. T-TEST

\begin{tabular}{|c|c|c|c|c|c|c|}
\hline \multicolumn{6}{|c|}{ Group Statistics } & \multirow[b]{2}{*}{ Sig } \\
\hline & Sex & $\mathrm{N}$ & Mean & $\begin{array}{c}\text { Std. } \\
\text { Deviation }\end{array}$ & $\begin{array}{l}\text { Std. } \\
\text { Error } \\
\text { Mean } \\
\end{array}$ & \\
\hline \multirow{2}{*}{$\begin{array}{c}\text { FamiliarW } \\
\text { ithDynami } \\
\text { cPassword } \\
\text { s }\end{array}$} & $\operatorname{man}$ & 45 & 1.98 & 1.076 & .160 & \multirow[t]{2}{*}{.020} \\
\hline & woman & 73 & 1.74 & .882 & .103 & \\
\hline \multirow{2}{*}{$\begin{array}{c}\text { FamiliarWit } \\
\text { hDIgitalCert } \\
\text { ificates }\end{array}$} & man & 45 & 2.29 & 1.100 & .164 & \multirow[t]{2}{*}{.001} \\
\hline & woman & 73 & 1.75 & .830 & .097 & \\
\hline \multirow{2}{*}{$\begin{array}{c}\text { FamiliarWit } \\
\text { hPhising }\end{array}$} & man & 45 & 2.24 & 1.264 & .188 & \multirow[t]{2}{*}{.000} \\
\hline & woman & 71 & 1.55 & .875 & .104 & \\
\hline \multirow{2}{*}{$\begin{array}{c}\text { FamiliarWit } \\
\text { hSSL }\end{array}$} & man & 45 & 2.13 & 1.254 & .187 & \multirow[t]{2}{*}{.000} \\
\hline & woman & 71 & 1.52 & .876 & .104 & \\
\hline
\end{tabular}

E. Hypothesis 2: Internet banking customers know the correct web address of their banks

Using ANOVA test this is shown only partially true. Only $56 \%$ of the internet banking customers knows the correct Web address of their. Significant influence does exist and it is less than 0.05 .

\section{DISCUSSION AND CONCLUSION}

Information systems are something that is constantly evolving, and because of that security of information is becoming more and more important. With the developing of information systems, banks are following trends and there are constant growth of the internet banking customers. In order to use the internet banking, customers should be familiar with the security of their information and threats that can invade their privacy and their bank accounts. Due to the importance of this topic, we decided to take a closer look at the needs of the internet banking customers.

Based on the results of first research question, it can be concluded that customers are not really familiar with the basic technologies and the main threats of internet banking. Reference [18] conducted a research study about customer awareness of internet banking security and concluded the same thing, that customers are not really familiar with internet banking security and they are not acquainted with basic technologies and the main threats of internet banking.

This is something that can be very dangerous, both for the customers and for the banks, because customers should know how to properly use their internet banking account in order to keep their information private and secure.

Regarding our second research question, it can be seen that customers are not really concerned about the security of their internet banking accounts. Reference [18] concluded the opposite. This can be explained with the difference between cultures, and that internet banking in Serbia is still developing, so customers may have not yet had problems with the security.
In third research question, we examined if internet banking customers consider that internet banking is safe and secure for using.

TABLE VI. ANOVA TEST

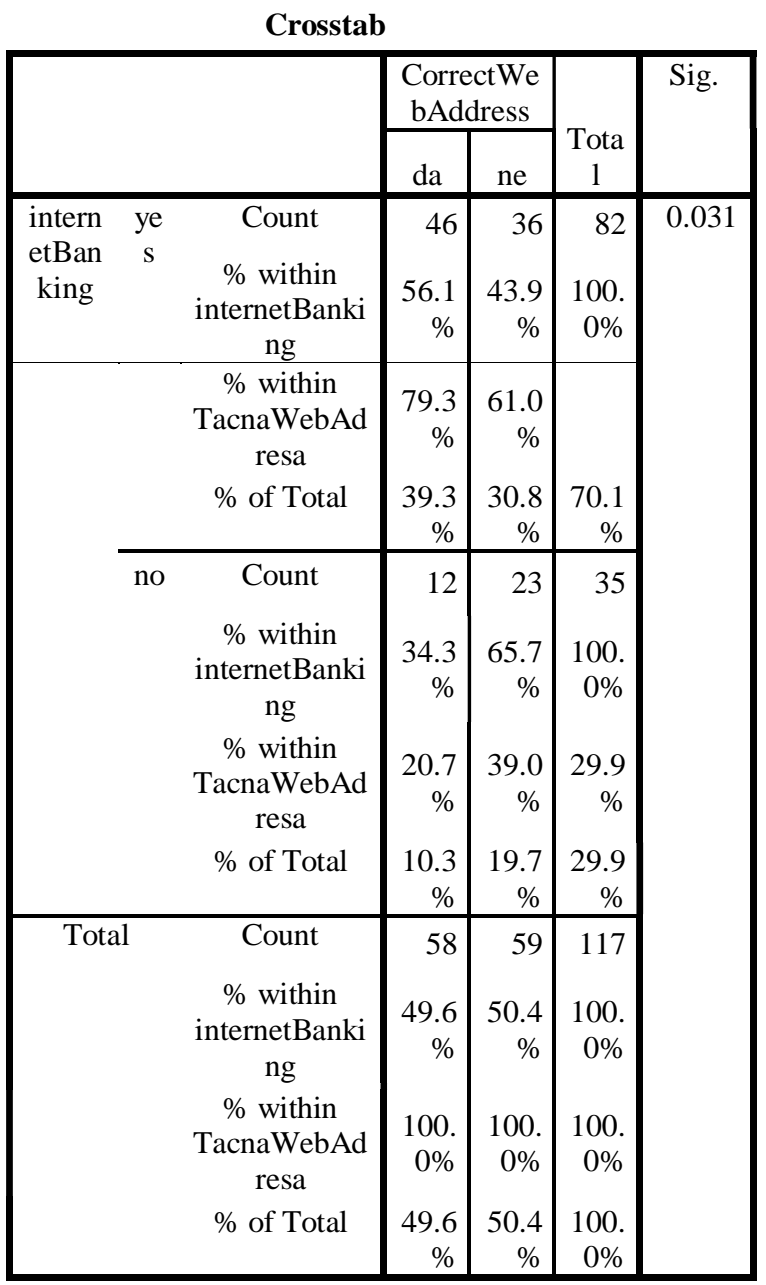

Most of the respondents (93\%) answered that they agree/strongly agree that in1ternet banking is secure, while [22] concluded that only $60 \%$ of the customers agree with this statement.

In first hypothesis, it can be concluded that there is significant difference between sexes about how familiar they are with information security. Man are shown to be more familiar with information security and with basic technologies and the main threats of internet banking (SSL, phishing, digital certificates and dynamic passwords).

Results from the second hypothesis are very interesting. It is shown that only $56 \%$ of the respondents who use internet banking knows the correct internet address of their banks. Combining this with the results from the research questions 1, especially with the familiarity with the phising where $56,7 \%$ of the respondents said that they never heard about it, it can be concluded that internet banking customers can be very vulnerable. The best way to avoid phising attacks and fake sites is to know how to 
recognize them, so both internet banking customers and banks should work on this issue.

\section{REFERENCES}

[1] K. Koskosas, K. Kakoulidis, and C. Siomos, "Examining the linkage between information security and end-user trust," International Journal of Computer Science and Information Security, vol. 9, pp.21-31, February 2011.

[2] H. B. Sharif, "Users' perception of the information security policy at University Teknologi Malaysia," Master Thesis, Universiti Teknologi Malaysia, Faculty of Computer Science and Information System, April 2009

[3] B. N. Nyaga, "Information security and service delivery in health sector: Case study of Chogoria hospital," Master thesis, University of Nairobi, School of business, November 2016.

[4] K. Berezina, C. Cobanoglu, B. L. Miller, and F. A. Kwansa, "The impact of information security breach on hotel guest perception of service quality, satisfaction, revisit intentions and word-of-mouth," International Journal of Contemporary Hospitality Management, vol. 24, pp.991-1010, September 2012.

[5] T. Beshah D. Medlin, and A. Abraham, "Patient's perception of health information security: The case of selected public and private hospitals in Addis Ababa," Sixth International Conference on Information Assurance and Security, August 2010.

[6] K. Renaud, and W. Goucher, "Health service employees and information security policies: an uneasy partnership?," Information Management \& Computer Security, vol. 20, pp.296-311, July 2012

[7] H. B. Sharif, Z. Ismail, and M. Masrom, "Users' perception on the information security policy of the institutions of higher learning," Universiti Teknologi Malaysia, Faculty of Computer Science and Information System, 2007

[8] A. N. Fajar, H. Christian, and A. S. Girsang, "Evaluation of ISO 27001 implementation towards information security of cloud service customer in PT. IndoDev Niaga internet," IOP Conf. Series: Journal of Physics: Conf. Series 1090, 2018.

[9] S. Bahl, and O.P. Wali, "Perceived significance of information security governance to predict the information security service quality in software service industry," Information Management \& Computer Security, vol. 22, pp.2-23, 2014
[10] D. Huang, P. P. Rau, and G. Salvendy, "Perception of information security," Behaviour \& Information Technology, vol. 29, pp.221-232, June 2010.

[11] Y. J. Lee, R. J. Kauffman, and R. Sougstad, "Profitmaximizing firm investments in customer information security," Decision Support Systems, vol. 51, pp.904-920, February 2011.

[12] R. K. Chellappa, and P. A. Pavlou, "Perceived information security, financial liability and consumer trust in electronic commerce transactions," Logistics Information Management, vol. 15, pp.358-368, 2002.

[13] V. Benson, G. Saridakis and, H. Tennakoon, "Information disclosure of social media users: Does control over personal information, user awareness and security notices matter?," Information Technology \& People, vol. 28, pp.426-441, 2015.

[14] V. V. Thai, "Determinants of customer expectations of service: Implications for fostering customer satisfaction," ISER-Science Plus International Conference, March 2015

[15] V. Zeithaml, L. Berry, and A. Parasuraman, "The nature and determinants of customer expectations of service," Journal of the Academy of Marketing Science, vol. 21, pp.1-12, 1993.

[16] T. Laukkanen, "Internet vs mobile banking: Comparing customer value perceptions," Business Process Management Journal, vol 13, pp.788-797, November 2007.

[17] I. Aboobucker, and Y. Bao, "What obstruct customer acceptance of internet banking security and privacy, risk, trust and website usability and the role of moderators," Journal of High Technology Management Research, vol. 29, pp.109-123, April 2018.

[18] R. Zhu, "Customer awareness of internet banking security in China,” WHICEB 2015 Proceedings, Jun 2015.

[19] N.Daud, N. Mamud, and S. Aziz, "Customer's perception towards information security in internet banking system in Malaysia," Australian Journal of Basic and Applied Sciences, vol. 5, pp.101-112, 2011.

[20] M. Bramhe, "SMS based secure mobile banking," International Journal of Engineering and Technology, vol. 3, pp.472-479, 2011.

[21] S.Islam, "Systematic literature review: security challenges of mobile banking and payment system," International Journal of $\mathrm{u}$ - and e- Service, Science and Technology, vol. 7, pp.107-116, 2014.

[22] F. Twum, and K. Ahenkora, "Internet banking security strategy: securing customer trust," Journal of Management and Strategy, vol. 3, 2012 